\title{
Research in epidemiology and community health in the medical curriculum: students' opinions of the Nottingham experience
}

\author{
J M ELWOOD, J C G PEARSON, R J MADELEY, R F A LOGAN, M W BEAVER, \\ P A GILliES, J LITTLE, AND A LANGHAM \\ From the Department of Community Medicine and Epidemiology, University of Nottingham, Queen's Medical \\ Centre, Nottingham NG7 $2 U H$
}

SUMMARY Medical students in Nottingham all complete an honours Bachelor of Medical Sciences course in one department including a research project. The honours programme in community health is described, with results from a survey of the 122 graduates since the medical school started. The 98 $(80 \%)$ responses showed high levels of satisfaction and gain from the programme, the great majority regarding the course as valuable, enjoyable, and giving both research skills and skills in interpersonal relationships.

Two unusual features of the Nottingham Medical School curriculum are the importance placed on community health sciences and the fact that every medical student does a research project which leads to a Bachelor of Medical Sciences degree with honours. This paper describes the honours year programme in community health and reports on a survey of all students who have experienced this course since the medical school started in 1970. The Nottingham curriculum has been described recently. ${ }^{1}$ After $5 \frac{1}{2}$ terms, including 91 hours of community health teaching, students enter the honours year programme, choosing one of seven departments. In community health, this programme consists of a 6 week course in research methods, a supervised project lasting 18 weeks, and 6 weeks of seminars which currently are on early diagnosis and international health. Thus students electing community health spend most of an academic year studying the subject in depth. After this experience students move to full time clinical study, including further community health teaching. ${ }^{12}$

\section{The survey}

In the spring of 1985 , questionnaires were sent to the last known address of all students who had completed the honours year in community health since the first such group in 1973 . Of 122 students, $98(80 \%)$ replied. A four page anonymous questionnaire was used, including structured and open questions, and these were coded by a research assistant (AL). The results were assessed within three time periods; 1973 to 1977 , 1978 to 1981 , and 1982 to 1985 . The first two periods correspond to the beginning and maturing of the medical school, increasing gradually from 40 to 130 students in the intake years. Students graduating from 1982 onwards experienced the effects of changes in leadership, staffing, and an increasing emphasis on analytical epidemiology and on clinical aspects even in the first two years.

\section{Results}

It was shown (table 1) that a majority of students were positively attracted to Nottingham by both the honours programme and the community emphasis; that they thought the programme very valuable, both as general education and as a training for medicine; and that it affected their skills and attitudes. Most students were glad that they had had to do the honours year and felt they had gained particularly from community health. In regard to career decisions, 46 ventured no opinion, being mainly still clinical students; of those responding, most said it had had some effect.

A comparison of graduating classes (table 2) showed that the proportion of students responding favourably has increased over time for all questions except a change in attitudes. The largest increases have been in the proportion of students keeping an interest in their project and publishing or presenting it. The proportion of high classification degrees has increased 
Table 1 Students' perceptions of the Honours B Med Sci programme from closed questions: numbers of respondents (total=98)

\begin{tabular}{|c|c|c|c|c|}
\hline Selection factors: & Very Positive & Positive & No influence & Negative \\
\hline $\begin{array}{l}\text { Influence on choice of medical } \\
\text { school of the Honours programme? }\end{array}$ & 18 & 48 & 32 & 0 \\
\hline $\begin{array}{l}\text { Influence on choice of medical school } \\
\text { of the community emphasis? }\end{array}$ & 29 & 47 & 22 & 0 \\
\hline Value of the Honours year: & Very & Fairly & Not very & Not at all \\
\hline How valuable was your experience? & 55 & 35 & 8 & $\mathbf{0}$ \\
\hline $\begin{array}{l}\text { How worthwhile, in terms of future } \\
\text { as a doctor? (non-response }=5 \text { ) }\end{array}$ & 41 & 37 & 11 & 4 \\
\hline $\begin{array}{l}\text { How useful in terms of general } \\
\text { education? }\end{array}$ & 56 & 37 & 4 & 1 \\
\hline General impressions: & Glad & No opinion & $\begin{array}{l}\text { Prefer } \\
\text { conventional }\end{array}$ & \\
\hline \multirow[t]{2}{*}{ Glad you had to do an honours year? } & 86 & 6 & 6 & \\
\hline & Yes & No & & \\
\hline $\begin{array}{l}\text { Made a difference to practical } \\
\text { or personal skills? (non response }=1 \text { ) }\end{array}$ & 81 & 16 & & \\
\hline Made a difference to attitudes? & 57 & 41 & & \\
\hline Gained from community health? & 85 & 13 & & \\
\hline Influenced choice of career posts & Great deal & $\begin{array}{l}\text { Some } \\
25\end{array}$ & $\begin{array}{l}\text { Not at all } \\
20\end{array}$ & $\begin{array}{l}\text { No opinion } \\
46\end{array}$ \\
\hline
\end{tabular}

Table 2 Students' perceptions of B Med Sci programme by year of graduation

\begin{tabular}{llll}
\hline & \multicolumn{3}{l}{ Year graduated B Med Sci } \\
\cline { 2 - 4 } & $1973-77$ & $1978-81$ & $1982-85$ \\
\hline Total respondents & 28 & 34 & 36 \\
\hline Percentage responding: & $\%$ & $\%$ & $\%$ \\
Very valuable in general & 46 & 53 & 67 \\
Very worthwhile for future as doctor & 39 & 32 & 53 \\
Very useful as general education & 50 & 58 & 61 \\
Glad I did it & 86 & 85 & 92 \\
Difference to practical or personal skills & 79 & 79 & 89 \\
Difference to attitudes & 64 & 44 & 67 \\
Gained from community health & 87 & 79 & 97 \\
Kept interest in project & 46 & 50 & 78 \\
Published or presented project & 13 & 21 & 53 \\
*Final degree classification: \% with & & & \\
first or upper second class degree & & & \\
All community health students & 43 & 59 & 81 \\
All students & 57 & 69 & 74 \\
\hline
\end{tabular}

*Based on all students, including non-responders; 122 community health, 1085 total students

throughout the medical school but has increased slightly more in community health.

In regard to skills gained through the programme (table 3), the most frequently mentioned was skills in research methods, but many students mentioned improvements in interpersonal skills, such as the ability to talk to patients. Many students also reported a change in their attitudes; these changes, where
Table 3 Skills gained and attitudes changed: 98 respondents

\begin{tabular}{|c|c|c|c|}
\hline & \multicolumn{3}{|c|}{ Number of comments } \\
\hline & $\begin{array}{l}\text { Research } \\
\text { methods }\end{array}$ & $\begin{array}{l}\text { Interpersonal skills } \\
\text { and confidence }\end{array}$ & $\begin{array}{l}\text { Role of } \\
\text { medicine }\end{array}$ \\
\hline Skills gained & 51 & 34 & 4 \\
\hline Attitudes changed & 26 & 12 & 13 \\
\hline $\begin{array}{l}\text { Gained specifically } \\
\text { from community health }\end{array}$ & 29 & 26 & 33 \\
\hline
\end{tabular}

described, were in increasing their respect and appreciation for the value of research, the importance of good interpersonal and doctor-patient relationships, and the aspects of medicine beyond hospital based care. In regard to perceived gains from community health rather than other departments, similar numbers of comments referred to the role and scope of medicine, research methods, and interpersonal skills and confidence.

In open questions, students were asked which aspect of the course gave them the most satisfaction and which the least, which topics they particularly liked and which they particularly disliked. The responses were coded by the topic and whether these were positive or negative comments.

The aspects receiving the most positive comments were the project work (53 comments) and the independence given by the programme (41), followed by research methods (21), discussions of the role of medicine, relating to the emphases put on prevention, 
the community approach, and Third World health (17), the seminars which covered a wide range of issues (18), interpersonal relationships (8), and staff relationships and supervision (7).

There were fewer negative comments (123) than positive comments (175). These referred to research methods (31), and various other parts of the teaching (30), the research project (27), problems of relationships with staff and of supervision (17), and the pressure of the course (10). The open questions were analysed by year but no large differences were seen.

\section{Discussion}

The response rate of $\mathbf{8 0 \%}$ is reasonably high for a study of this nature. While non-responders might over represent those with a negative experience of the department, the marks and degree classifications gained by non-responders were typical of the whole group, and most failures to respond probably represent failure to locate graduates because of incorrect addresses, temporary work or elective assignments. Graduates of the programme are self selected for their interest in community health, as for the great majority ( 89 of 98 ) this was their department of choice for the honours year. Most of these students had been attracted to Nottingham both by the existence of the honours programme and by the community emphasis of the whole course. Even so, the levels of satisfaction expressed are very high, the great majority of students feeling that the experience was worthwhile and one that provided them with new skills and changed attitudes. Only 52 respondents felt able to comment on the influence of the year on their choice of career post, the others still being students, but of these the majority $(62 \%)$ said the programme had some influence. Five students gave their career choice as community medicine, three as Third World medicine, and two as research or academic medicine; so most of these influences related to the choice between general practice and hospital medicine, or more general issues.

The open-ended questions showed that students valued the independence offered, the research projects, and the interpersonal skills and confidence engendered by working with patients. The department's policy has been to encourage the students to use their own initiative, either by developing their own ideas or developing a project from a general outline suggested by the department. Laboratory based departments often give a more restricted choice of topic. The nature of community health research, including the options of working outside Nottingham and outside the United Kingdom, demands that the student carries out his field work
Logan, $M W$ Beaver, $P$ A Gillies, $J$ Little, and A Langham

with much less direct supervision than can be given in a laboratory based discipline. This provides greater opportunities for the committed and industrious student, but also the possibility of a greater workload and a more difficult project than might arise from a laboratory based study. Most projects involve extensive patient contact, again not always found in laboratory based projects, not only through the research itself, but also as arrangements are made for students to visit clinics, operating theatres, and general practice units to see patients and physicians and to gain a background knowledge of their subject.

The considerable although smaller number of negative comments concerning the project relate to its difficulty, length and workload, to issues of supervision and staff relationships, and to the fact that many projects do not produce clear or important results. The students' opinions confirm our impression that the projects are challenging and demanding, and encourage independence and clinically related skills, but consequently demand a lot from the student and from the supervisor. The survey results indicate that care must be taken to ensure that projects are realistic, and that supervisor-student relationships are good.

More negative than positive comments applied to the research methods courses, which are quite difficult and concentrated. However, many students indicated that part of their satisfaction was gained from being able to apply such methods, and most respondents put research methods as the main skill they had gained from the year.

It is relevant that 29 students, including 17 of the 36 graduates in the 82-85 phase, gave research methods? as something gained particularly from community health, as all other departments teach their own research methods to the same level. The comments show that these students feel that the methods they have learnt are positively useful in their further careers, and since 1981 greater emphases have been put on the application of epidemiological methods to clinical issues, and to critical evaluation of current medical literature.

The differences in responses by year give indications of the effect of changes in the department's orientation. The results are similar from 1973-77 and 1978-81, during which time the department had a similar orientation and structure. Students graduating since 1982 have experienced a greater emphasis on analytical epidemiological methods and their relevance to current clinical problems. The proportion of students who keep an interest in their project work, and who publish or present it, has increased. While more recently graduated students are referring to a shorter time period in regard to maintaining interest, the increase in publications may underestimate the difference as some graduates complete presentation or 
publication of their work some years after graduating. The increase in the proportion of projects published or presented reflects a deliberate policy change to encourage this and to subject the proposed protocols to close scrutiny to maximise the value of the project. Projects published between 1983 and 1985 are referenced 3 to 19 .

In summary, we conclude that the opportunity to study community health and epidemiology in depth during the medical undergraduate programme is attractive to many students on entry and is regarded as useful and enjoyable by the great majority of those who experience it. The programme not only provides skills in research techniques but also increases the students' self confidence and skills in interpersonal and doctor/patient relationships. The work done is seen as relevant to clinical medicine, provides a continuing interest for many graduates, frequently allows the student to publish or present some original work, and often influences their career development.

We are grateful primarily to Emeritus Professor EM Backett, whose efforts led to high priority being given to this programme in the medical school, to all previous members of the department's staff, and to the many others who have assisted in the conduct of these projects. We are grateful also to all the graduates who responded to this survey.

\section{References}

${ }^{1}$ Elwood JM, Epidemiology and community health in the medical curriculum: the Nottingham experience. $J$ Epidemiol Community Health 1985; 39: 185-93.

2 Miller DS, Backett EM, Vaughan JP. After the hospital episode. Lancet 1985; ii: 545 .

3 Jelley DM*, Madeley RJ. Antenatal care in Maputo, Mozambique-an analysis of risk factors and action taken. J Epidemiol Community Health 1983; 37: 111-6.
${ }^{4}$ Jelley DM*, Madeley RJ. Primary care in practice-a study in Mozambique. Social Science and Medicine 1984; 19(8): 773-82.

5 Madeley RJ, Jelley DM*, O'Keefe P. The advent of primary health care in Mozambique. Ambio 1984; 12(6): $322-5$.

${ }^{6}$ Williams R*, Gillies PA. Do we need objective measures to validate self-reported smoking? Public Health 1984; 98: 294-8.

${ }^{7}$ Elwood JM, Cotton RE, Johnson J, Jones GM*, Curnow $\mathrm{J}^{*}$, Beaver MW. Are patients with abnormal cervical smears adequately managed? Br Med J 1984; 289 891-4.

${ }^{8}$ Mann RG*. Why patient participation groups stop functioning: general practitioners' viewpoint. $\mathrm{Br}$ Med J 1985; 24: 209-11.

${ }^{9}$ Caplan $\mathbf{M}^{*}$, Madeley $\mathbf{R}$. Home births in Nottingham 1980-81. Public Health 1985; 99: 307-13.

${ }^{10}$ Webb $N^{*}$, Hull D, Madeley RJ. Care by parents in hospital. Br Med J 1985; 291: 176-7.

11 Stamp EJ*, Jones SJ, Ryrie DR, Hedley AJ. Oral anticoagulants: a cost-effectiveness approach. $J$ Roy Coll $P$ 1985; 19(2): 105-8.

12 Webster $F^{*}$, Elwood JM. A study of the influence of ovulation stimulants and oral contraception on twin births in England. Acta Genet Med Gemollol 1985; 34: 105-8.

13 Nguyen-Van-Tam JS*, Pearson JCG. Adolescents' desires and beliefs about motorcycling: implications for education. Health Education Journal 1985; 44: 146-8.

14 Rhodes $K^{*}$, Gillies PA. Parents views of health and educational services for pre-school Down's syndrome children. Br J Mental Subnormality 1985; 32: 61(2).

${ }^{15}$ Karmali J*, Madeley RJ. Mothers' attitudes to a child health clinic in a deprived area of Nottingham. Public Health 1986; 100: 156-65.

16 Elwood JM, Williamson C*, Stapleton PJ. Malignant melanoma in relation to moles, pigmentation and exposure to fluorescent and other lighting sources. $\mathrm{Br} J$ Cancer 1986; 53: 65-74.

${ }^{17}$ Densem S*, Gillies PA. Methodology in practicemeasuring height and weight in school populations. $J$ Roy Soc Health 1986; 6: 82-4.

18 Rashiq S*, Logan RFA. Role of drugs in fractures of the femoral neck. Br Med J 1986; 292: 861-3.

${ }^{19}$ Nguyen-Van-Tam JS*, Pearson JCG. Teenagers and motorcycles-knowledge and perception of risks. $J$ Inst Health Education (in press).

Note:

In references 3 to 19 , undergraduates' names are indicated thus*. 